\title{
Tujeroden lipov listni zavrtač Phyllonorycter issikii (Kumata, 1963) od leta 2006 tudi v Sloveniji
}

\section{Maja JURC}

Lipov listni zavrtač, Phyllonorycter issikii (Kumata, 1963) (Lepidoptera: Gracillariidae), je vzhodno azijski metulj, ki je bil opisan na Japonskem, razširjen je tudi v Koreji in na Kitajskem. V evropskem delu Rusije je bil najden leta 1982, od takrat se je razširil v 20 evropskih držav in ima vse značilnosti invazivne tujerodne vrste (Avstrija, Belorusija, Bolgarija, Češka republika, Estonija, Hrvaška, Finska, Italija, Litva, Latvija, Madžarska, Nemčija, Nizozemska, Poljska, Romunija, Rusija, Slovaška, Slovenija, Švica in Ukrajina). Leta 2000 so ga odkrili v severni Avstriji in na Madžarskem, leta 2005 na Hrvaškem, pri nas pa leta 2006. Zadnji najdbi sta bili v Švici in na Nizozemskem leta 2009. Gostitelji $\mathrm{Ph}$. issikii so rastline iz redov Malvales in Fagales. V Aziji so to predvsem Tilia japonica Simonkai, $T$. maximowicziana Shirasawa, T. kiusiana Makino et Shirasawa, T. amurensis Rupr., T. mandshurica Rupr. in Betula platyphylla Sukacz. $=$ B. pendula Roth. (zadnji gostitelj ni potrjen). V Evropi so gostitelji T. cordata Mill., T. platyphyllos Scop., T. tomentosa Moench , njihovi hibridi in tujerodne vrste lip.

$P h$. issikii je majhen metulj, odrasel osebek čez razpon kril meri od 7 do 7,5 mm (slika 1). Barva kril sezonsko variira. Ima dve generaciji letno: metulji prve generacije letajo od konca junija do sredine julija, metulji druge generacije pa od konca julija do konca avgusta. Prezimijo bube (slika 3) in odrasli metuljčki (slika 1). Gosenice (slika 2) oblikujejo relativno velike izžrtnine (mine) na lipovih listih (slika 4, slika 5, slika 6). Na krajše razdalje se širi z letenjem, na daljše razdalje $s$ prenosom jajčec, gosenic in bub $\mathrm{z}$ napadenim rastlinskim materialom, ali z odpadlim listjem (s prstjo).

V Sloveniji smo lipovega listnega zavrtača našli leta 2006 na Rožniku v Ljubljani. Leta 2006 so ga opazili tudi v gozdnem sestoju v bližini Kranja (osebna komunikacija, S. Gomboc). V obdobju 2007-2008 smo opravili raziskavo napadenih lip (T. cordata, T. platyphyllos, T. tomentosa, T. sp.1, T. sp.2) v šestih ekoloških regijah na 22 lokacijah (Ajdovščina, Brežice, Črniče, Dobravlje, Gerečja vas, Ljubljana-vrt Gozdarskega inštituta Slovenije, Krško, Ljutomer, Mokronog, Novo mesto, Ribnica, Rožna dolina pri Novi Gorici, Straža, Šempas, Šmarjeta, Trebnje, Turjak, Željne, Ljubljana vrt Oddelka za gozdarstvo in obnovljive gozdne vire, Pernica, Ižakovci, Blejska dobrava). Ugotovili smo, da je $P h$. issikii prisoten v celi Sloveniji: največja velikost populacije (število izžrtin na listih) je bila v Predalpski, Predpanonski in Alpski ekološki regiji, mine so bile največje v Predalpski, Alpski in Predpanonski ekološki regiji. Po številu izžrtin na listih je od avtohtonih lip na prvem mestu T. cordata (91,47 izžrtin / 100 listov), sledi T. platyphyllos (21,72 izžrtin / 100 listov) in $T$. tomentosa (8,41 izžrtin / 100 listov). Daleč največje število izžrtin se pojavlja na lipi T. sp.1 (512,50 izžrtin / 100 listov). Ugotavljali smo poškodovanost listja (število izžrtih listov od skupnega števila listja na veji): v letu 2007 je bila poškodovanost listja večja v primerjavi z letom 2008 (poškodovanost listja lip leta 2007 je bila $116 \%$, leta 2008 pa 66,48 \%, v povprečju v obeh letih pa 87,80 \%). Prav tako je bila povprečna velikost izžrtin večja leta 2007 v primerjavi z letom 2008. Velikost posamične izžrtine je v naši raziskavi leta 2007 znašala 39,26 mm² $\pm 5,37 \mathrm{~mm}^{2}$, v letu 2008 pa $21,43 \mathrm{~mm}^{2} \pm 3,13 \mathrm{~mm}^{2}$. Naša raziskava je pokazala relativno veliko poškodovanost domačih in hibridnih (eksotičnih) vrst lip. Na Rožniku v Ljubljani je bila poškodovanost lip v letu 2011 še močnejša (v jesenskem času smo ugotovili do 20 izžrtin na enem listu $T$. platyphillos) (slika 4, slika 5, slika 6).

Raziskovalci ugotavljajo, da se $P h$. issikii hitro širi v nova področja Evrope, posebej v urbanih območjih. Predstavlja resno nevarnost za številne vrste lip, ki jih uporabljajo $\mathrm{v}$ okrasne namene, $\mathrm{v}$ zadnjem času se pojavlja tudi v gozdnih območjih v bližini večjih mest.

\section{Viri}

Jurc M. 2011. Update on the situation of the lime leafminer (Phyllonorycter issikii (Kumata, 1963) in Europe and in Slovenia, 14 str. (v tisku)

Kumata, T. 1963. Taxonomic Studies on the Lithocolletinae of Japan (Lepidoptera: (Gracillariidae), Part I, Insecta Matsumurana, 25, 2: 53-90.

Šefrová, H. 2002. Phyllonorycter issikii (Kumat a, 1963) - Bionomics, Ecological Impact and Spread in Europe (Lepidoptera, Gracillariidae), Acta Univ. Agric. et Silvic. Mendel. Brun., 50, 3: 99104.
1 Univerza v Ljubljani, Biotehniška fakulteta, Oddelek za gozdarstvo in obnovljive gozdne vire, Večna pot 83, 1000 Ljubljana *maja.jurc@bf.uni-lj.si 


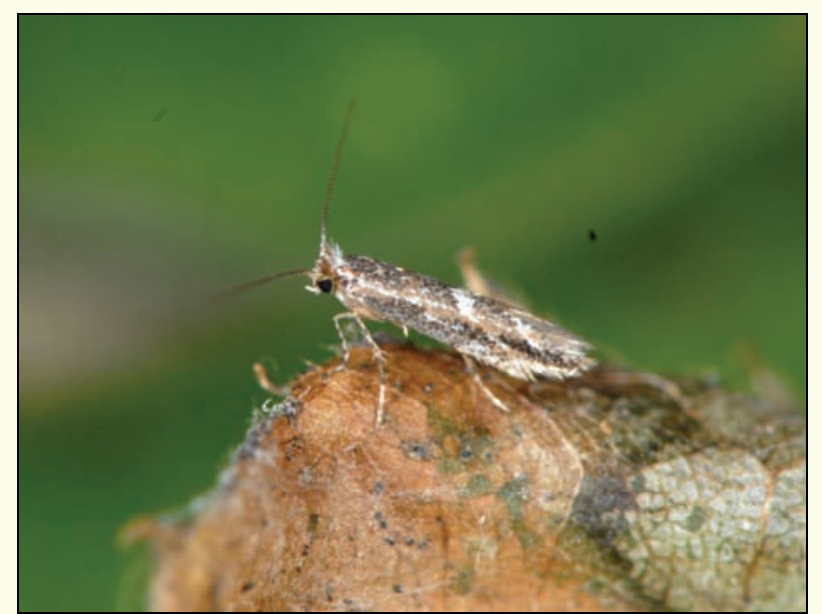

Slika 1: Tujeroden lipov listni zavrtač (Phyllonorycter issikii) meri čez razpon kril od 7 do 7,5 mm (foto: M. Jurc)

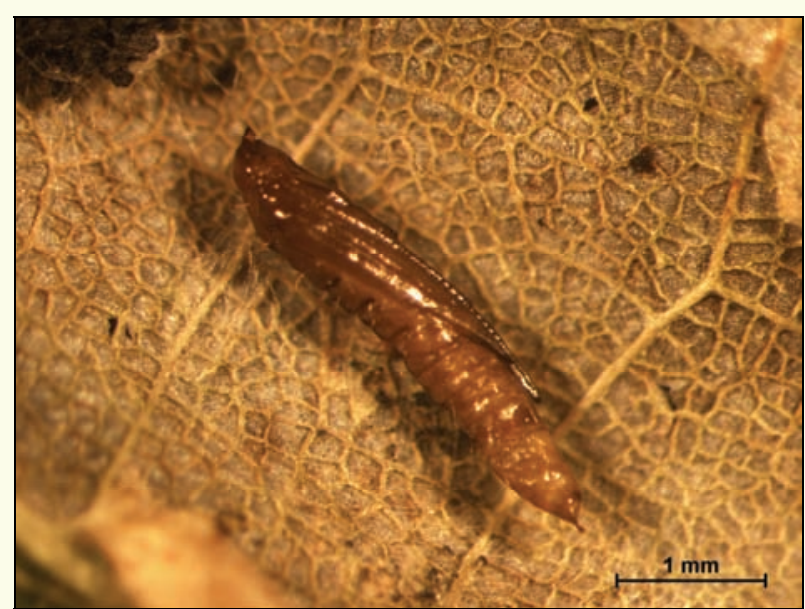

Slika 3: Kamrica z bubo (foto: M. Jurc)

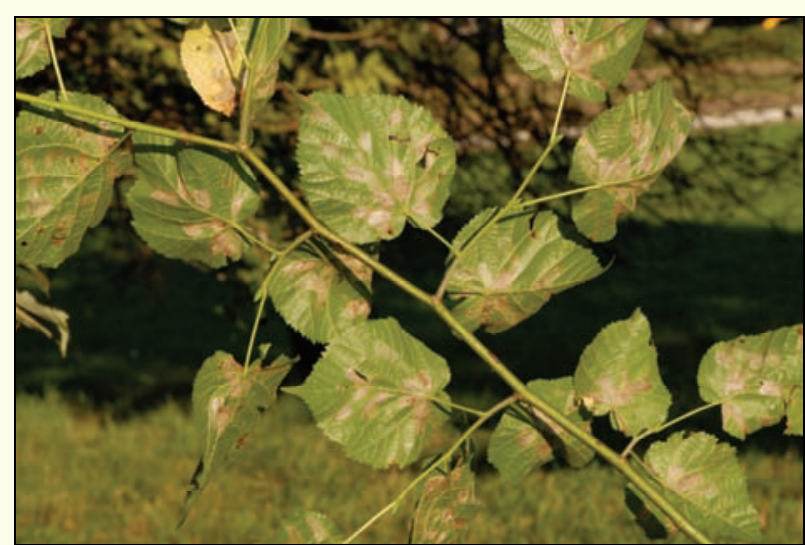

Slika 5: Izžrtine na spodnji listni ploskvi (foto: M. Jurc)

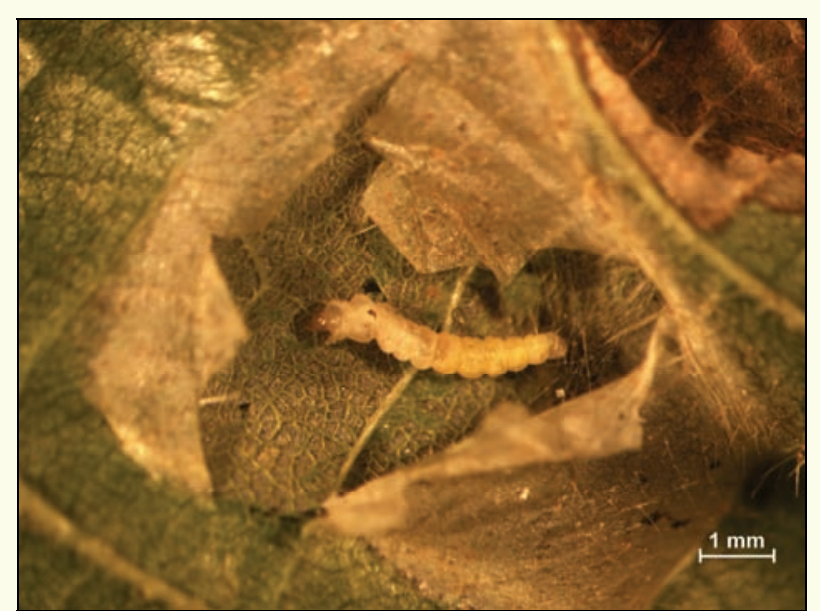

Slika 2: Kamrica z ličinko (foto: M. Jurc)

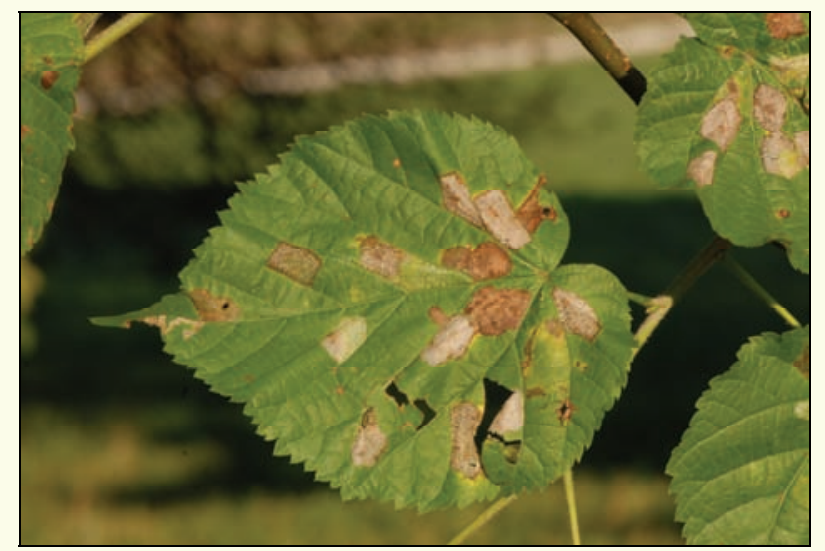

Slika 4: Poškodovan list T. platyphillos (foto: M. Jurc)

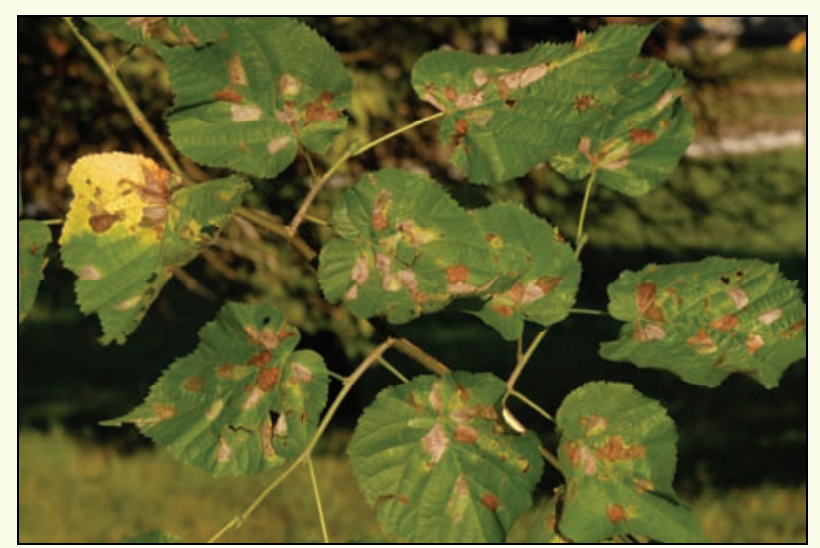

Slika 6: Izžrtine na zgornji listni ploskvi, 24.9.2011, Jesenkova pot, Ljubljana (foto: M. Jurc) 